\title{
МЕТОДИЧНІ ПІДХОДИ ЩОДО ЗМІНИ ФОРМИ ВЛАСНОСТІ ЗАЛІЗНИЦЬ
}

\author{
Позднякова Л.О., д.е.н., професор, \\ Дейнека О.Г., д.е.н., професор (УкрДУЗТ)
}

В статті авторами розглядається актуальна проблема зміни форми власності вітчизняних залізниць. Вивчено та узагальнено зарубіжний досвід приватизації та запропоновано механізм, який забезпечує підвищення ефективності вітчизняних залізниць. Встановлено сутність, поняття та принципи приватизачії з точки зору загальної теорії на основі напраџювань зарубіжних та вітчизняних вчених, на иүій підставі, визначено переваги та недоліки різноманітних форм власності.

Ключові слова: форма власності, приватизація, зарубіжний досвід.

\section{МЕТОДИЧЕСКИЕ ПОДХОДЫ К ИЗМЕНЕНИЮ ФОРМЫ СОБСТВЕННОСТИ ЖЕЛЕЗНЫХ ДОРОГ}

\author{
Позднякова Л.А., д.э.н., профессор, \\ Дейнека А.Г., д.э.н., профессор (УкрГУЖТ)
}

В статье авторами рассматривается актуальная проблема изменения формы собственности отечественных железных дорог. Изучено и обобщено зарубежный опыт приватизации и предложен механизм, обеспечивающий повышение эффективности отечественных железных дорог. Установлена сущность, понятие и принциипь приватизащии с точки зрения общей теории на основе наработок зарубежных и отечественных ученых, на этом основании, определено преимущества и недостатки разнообразных форм собственности.

Ключевые слова: форма собственности, приватизация, зарубежный опыт.

\section{METHODICAL GOING NEAR CHANGE OF PATTERN OWNERSHIP OF RAILWAYS}

Pozdnyakova L.A., doctor of economic sciences, professor, Deinek A.G., doctor of economic sciences, professor (USU of RT)

In the article authors are examine the issue of the day of change of pattern of ownership of home railways. Foreign experience of privatizing is studied and generalized and a mechanism offers, providing the increase of efficiency of home railways. Essence, concept and principles of privatizing, is set from the point of view of general theory on the basis of works of foreign and home scientists, on that ground, advantages and lacks of various patterns of ownership are certain. On the basis of it factors and methods of privatizing, basic directions of reformation of property, are certain, the selection of positive factors to privatizing is done and the mechanism of priorities of роздержавлення is worked out.

Keywords: pattern of ownership, privatizing, foreign experience.

\begin{abstract}
Постановка проблеми. В умовах ринкових відносин суспільство охоплює корінні перетворення. Відбувається становлення нової економічної системи, змінюються економічні відносини. Однією з характерних рис забезпечення розвитку економіки є іiі корінна зміна державного регулювання підприємствами. Це зумовлюється низькою ефективністю виробництва, значними структурними диспропорціями, підривом фінансово-економічних інститутів, неефективною системою управління, планування і регулювання народним господарством у цілому та залізничним транспортом. Це визначає необхідність вироблення наукових уявлень про майбутню модель державного управління, контролю і регулювання економічних
\end{abstract}

процесів, які виникають в галузі. Актуальність теми дослідження обумовлена тим, що 3 наукових позицій доцільно оцінити об'єктивну необхідність трансформації відносин власності, яка зумовлює, перш за все, зміну ролі держави в економіці за рахунок роздержавлення.

Аналіз останніх досліджень і публікацій. Світова практика свідчить про традиційний, 3 погляду ринкових пріоритетів, напрямок вивчення питань, пов'язаних зі зміною форми власності у зв'язку зі збитковістю їх діяльності приватизацією. Особливий внесок у розвиток цієї проблеми в науці здійснили такі вчені, як В. Андрефф та Т.Розбард [1]; М.Фрідмен, Р.Маржолен, Р.Прайк [2]; Дж.Гелбрейт, Дж.Робінсон [3] та ін. Вивченням (с) Позднякова Л.О., Дейнека О.Г.
Вісник економіки транспорту і промисловості № 50, 2015 
питань щодо приватизації займалися й вітчизняні вчені, а семе: І. Бондар, В. Бесєдін [4]; Л. Верховодов, П. Кучерявенко [5]; Ю. Ехануров, 3. Мочерний [6]; М. Чечетов [7]; Р.Свстигнєєв, П.Буніч, В.Медведєв [8] та ін. Однак окремі питання приватизації $\epsilon$ недостатньо розкриті, тому було розглянуто фактори вибору моделі приватизації та методи приватизації.

Виділення невирішених частин загальної проблеми. Вивчення стану і роботи залізничного транспорту, визначення тенденцій розвитку i ступеня взаємодії з державою, а також розроблення напрямку і рівнів розвитку на перспективу.

На сучасному етапі теоретичні i практичні основи вирішення поставленої проблеми на залізничному транспорті розроблені не в повній мірі. Питання про визначення тенденцій розвитку галузі у взаємодії зі зміною державного регулювання залишаються відкритими. Таким чином, дослідження вважається актуальним.
Мета дослідження полягає в обгрунтуванні теоретичних і методологічних підходів й концептуальних основ 3 трансформації форм власності.

Викладення основного матеріалу дослідження. В процесі дослідження розкрито правову базу і принципи державного регулювання і контролю на основі законів України. Встановлено сутність, поняття та принципи приватизації з точки зору загальної теорії на основі вивчення результатів напрацювань зарубіжних та вітчизняних вчених, на цій підставі, визначено переваги та недоліки різноманітних форм власності. Вивчено теоретичні, методологічні і практичні питання реформування відносин власності. На основі цього визначено фактори та методи приватизації (рис. 1), основні напрямки реформування власності (рис. 2), зроблено виділення позитивних чинників приватизації та розроблено механізм пріоритетів роздержавлення. Проведене дослідження виконано у поєднанні 3 встановленням негативних сторін приватизації.

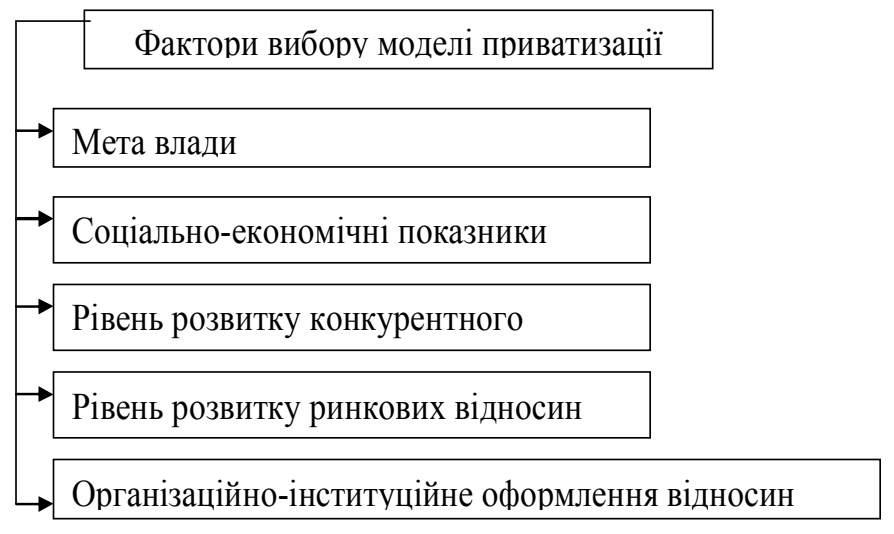

Рис. 1. Чинники вибору моделі приватизації України

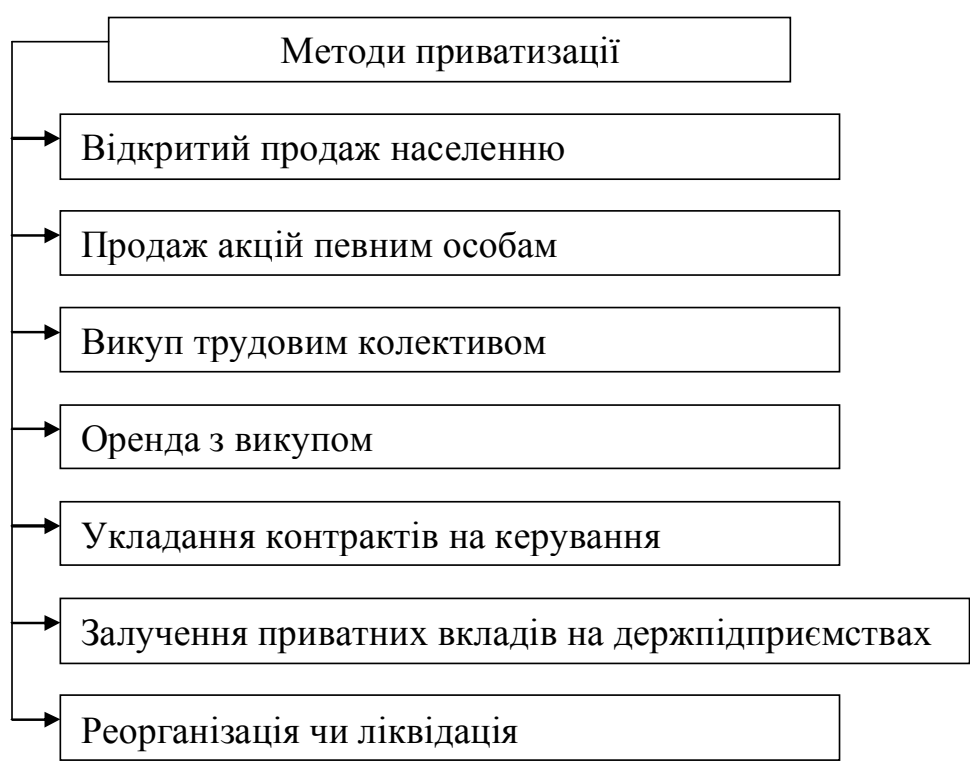

Рис. 2. Методи приватизаиіiі 
На підставі виконаного дослідження класифіковано об'єкти, які не підлягають приватизації, серед яких: майно органів державної влади i управління, золотий i валютний фонди, комплекси по виготовленню цінних паперів i грошових знаків, майно збройних сил, державні матеріальні резерви, національні, культурні і історичні цінності.

Встановлено, що реалізація мети приватизації обумовлена вирішенням конкретних програм приватизації та переслідує декілька задач, які дозволили класифікувати цілі приватизації відповідно форми роздержавлення. Доведено, що усе різноманіття форм роздержавлення економіки України можна класифікувати за трьома ознаками роду, типу і вигляду.

В процесі дослідження визначено моделі приватизації, до яких можна віднести дві основні: платну й безоплатну. Кожна 3 них визначає умови приватизації. Науково обгрунтовано і класифіковано етапи проведення приватизації в Україні: з моменту утворення і становлення Фонду державного майна; проведення приватизації за винятком об єктів малої приватизації переважно шляхом орендування; проведення масової приватизації за приватизаційні папери із залученням широких верст населення; завершення сертифікаційної та перехід до грошової приватизації.

На підставі зробленого аналізу авторами узагальнено та промодельована теорію приватизації Центральної та Східної Свропи, країн з розвинутою економікою, та окремо обраних держав, таких як: Великобританія, Франція, Канада. Представляють інтерес моделі приватизації Великобританії, яка наведена на рис. 3 та країн з розвинутою економікою, яка наведена на рис. 4.

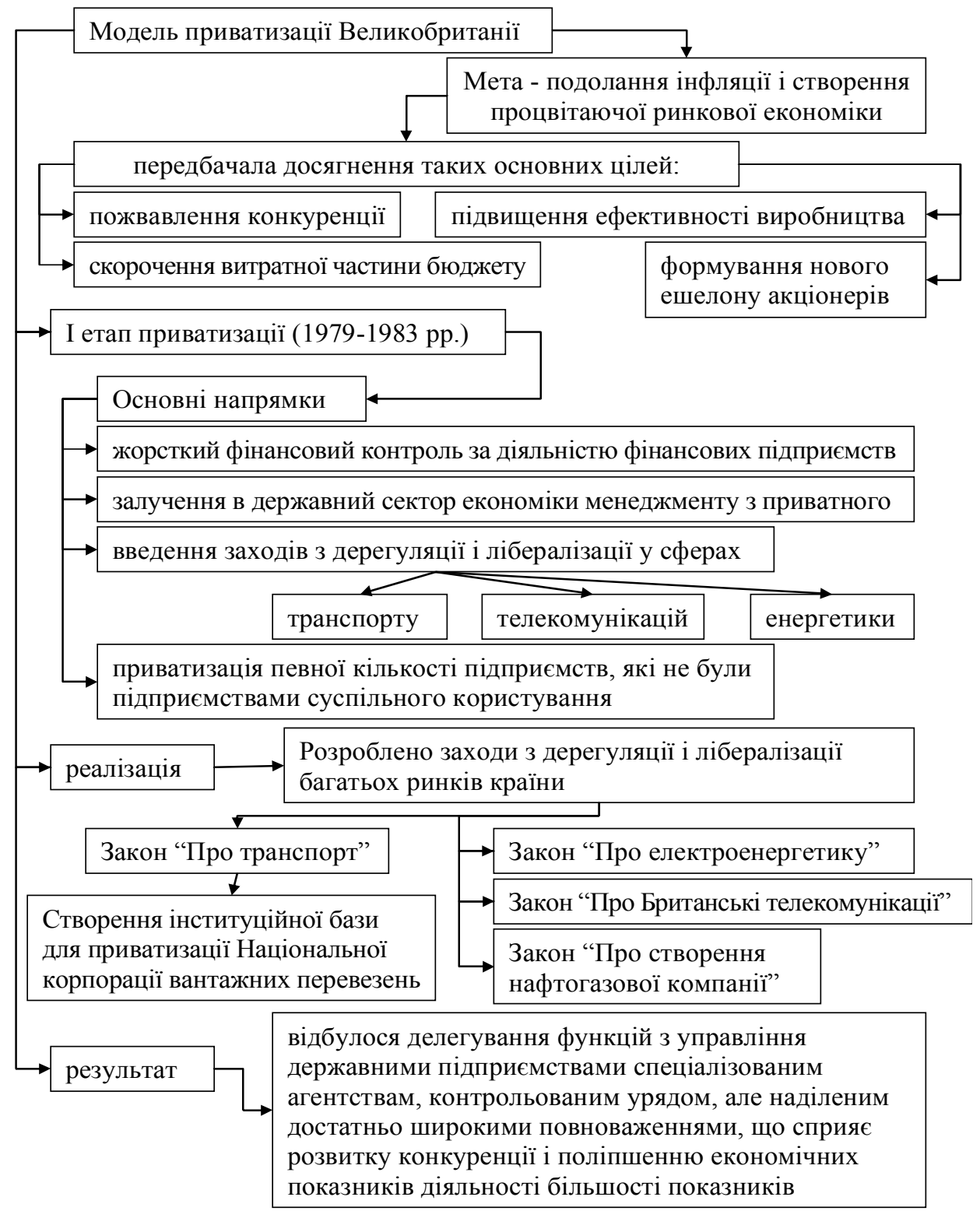

Рис. 3. Модель приватизайї Великобританії 


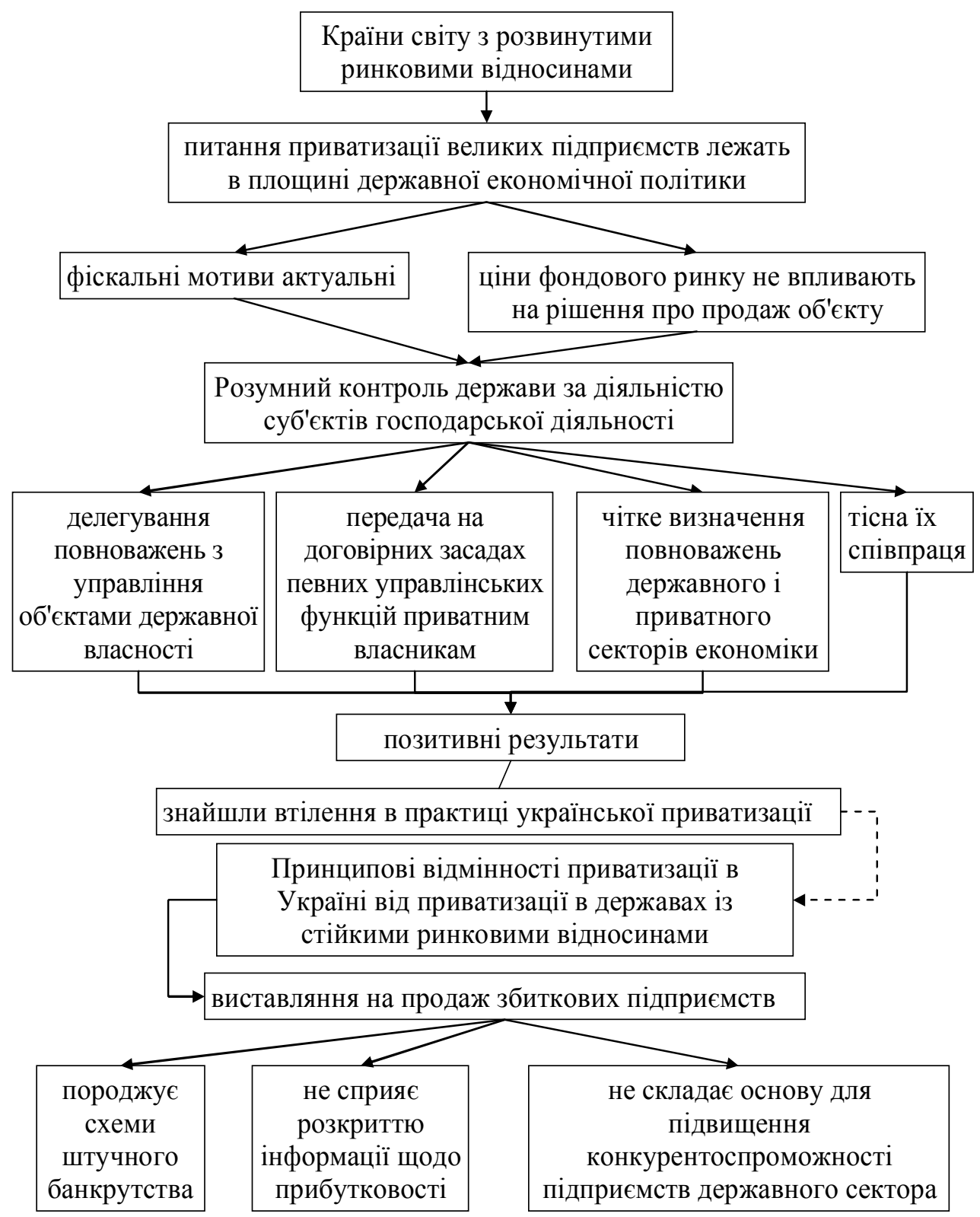

Рис. 4. Модель приватизаиії крайн з розвинутою економікою

В останній моделі визначено напрямки запозичення досвіду та принципові відмінності, які використовувались в Україні, що $\epsilon$ елементом наукової новизни.

Дослідженням встановлено, що здійснення приватизації передбачає такі основні етапи: перед приватизаційна підготовка об'єктів; підготовка об'єктів до продажу, продаж об'єктів відповідно до плану приватизації або плану розміщення акцій ВАТ, створених шляхом корпоратизації.

Заключний етап приватизації об'єктів України, як політичного та соціального проекту, основним призначенням якого $€$ трансформація відносин власності і розвитку ринкових відносин економіки, та необхідністю, яка передбачає формування дієвої системи управління об'єктами державної власності.
Проведені соціологічні дослідження про приватизацію свідчать про те, що в переважаючій більшості приватизованих підприємств є торгівля, до якої відносяться 29\%, промисловість - 28\%, побутове обслуговування населення - 21\%, будівництво - $11 \%$, громадське харчування - 7\%. В залежності від віку переважна молодь в трансформації власності бачать реальні перспективи для вільної творчої власності, зростання можливостей та самореалізації, розвитку комерційної діяльності.

Респонденти старшого віку головними результатами вважають безробіття, масові неплатежі, погіршення матеріального положення, розділення суспільства на забезпечених i незабезпечених. 
Теоретично обгрунтована доцільність зміни форми власності дає підставу для комплексного аналізу організаційної системи управління залізничним транспортом 3 метою отримання недоліків у діючій структурі управління. Тому проаналізовано хронологічні моделі структури управління залізниць світу, таких як: Німеччина, Швейцарія та Польща, які наведено на рис. 5, 6, 7.

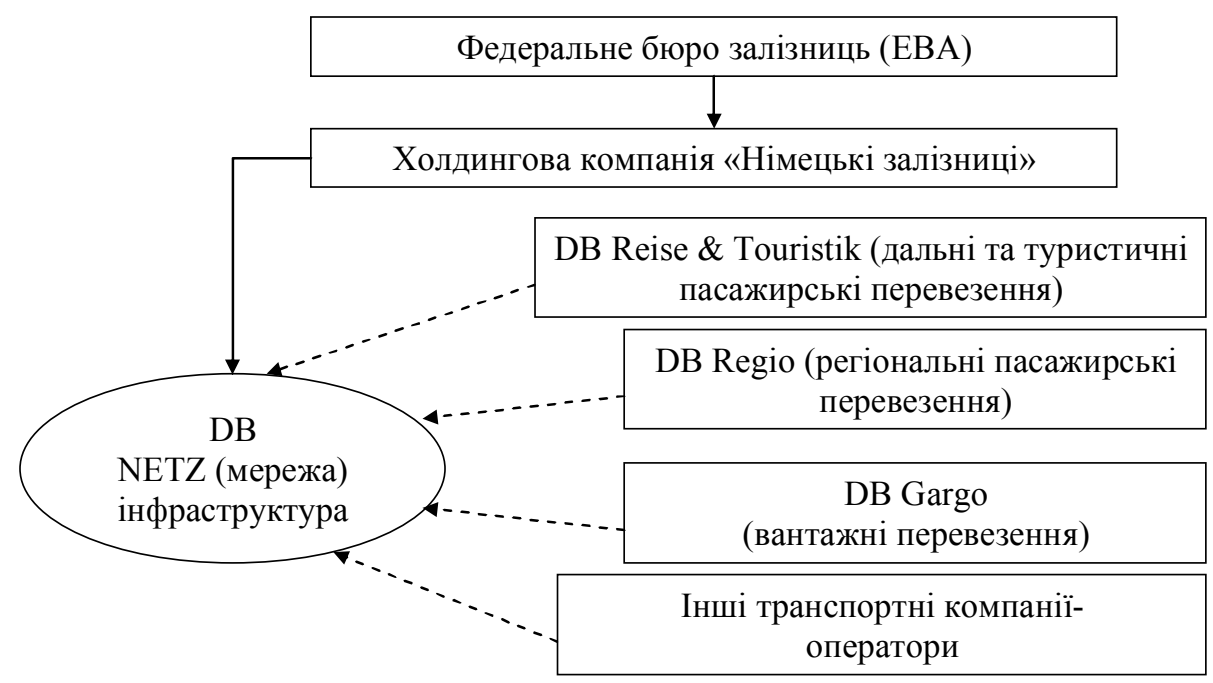

Рис. 5. Структура залізниць Німеччини

Відповідно до схеми управління наступними складовими: на пасажирські та залізничним транспортом Польщі в Україні було вантажні перевезення, інфраструктуру, рухомий адаптовано діючу Номенклатуру витрат за склад та ремонт.

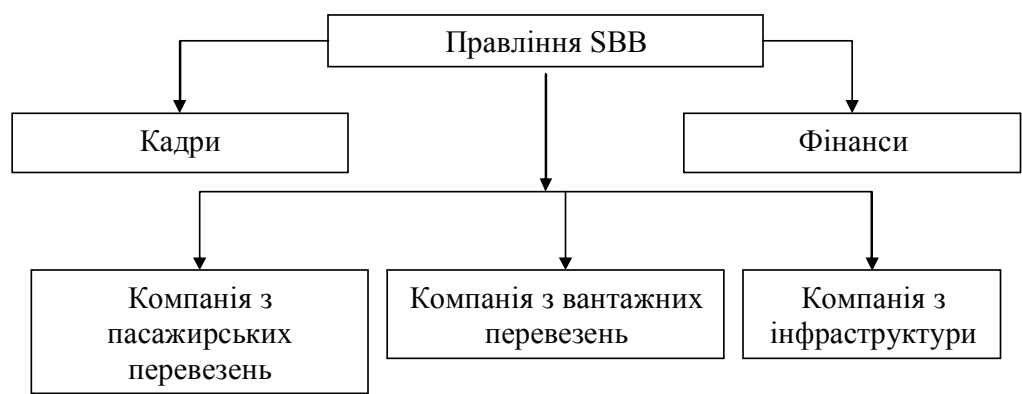

Рис. 6. Структура Федеральних залізниць Швейцарії

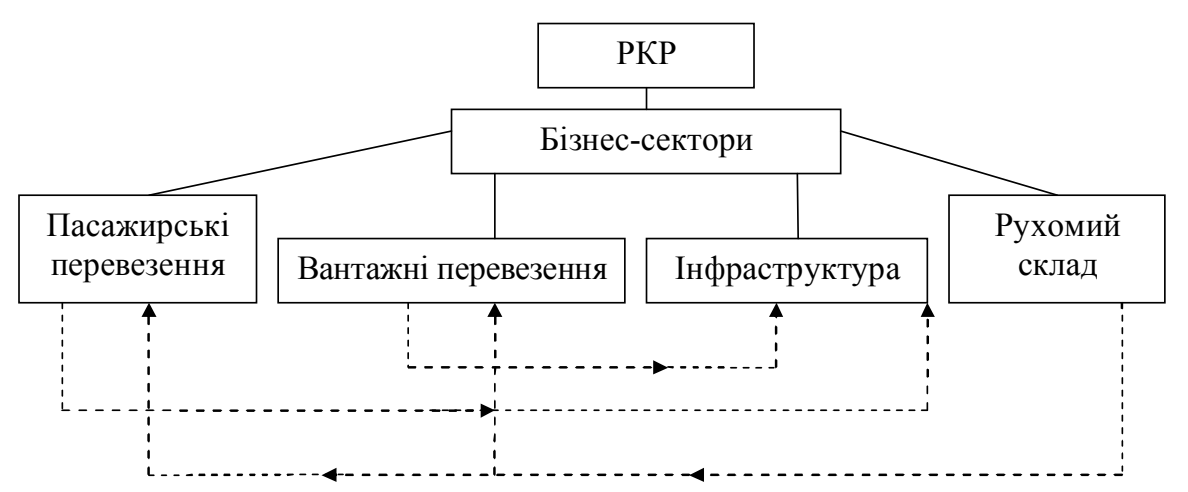

Рис. 7. Схема управління залізничним транспортом Польщзі

Висновок. Таким чином, вивчено теоретичні підходи щодо проблеми проведення приватизації у світі та в Україні. Визначено поняття, сутність, принципи та методи приватизації. Доведено, що усе різноманіття форм роздержавлення економіки України можна класифікувати за трьома ознаками 
- родом, типом і видом. Теоретично обгрунтовано напрямки сучасного приватизаційного процесу та ефективну стратегію реструктуризації.

Визначено передумови здійснення приватизації окремих підприємств залізничного транспорту зі зміною власника шляхом перетворення державної власності в недержавну та роздержавлення другого роду, яке не пов'язане зі зміною типу власності. На підставі досвіду здійснення приватизації було сформульовано принципи, за якими вона здійснюється.

\section{СПИСОК ЛІТЕРАТУРИ}

1. В. Андрефф. Новая корпоративная стратегия/ В. Андрефф, Т. Розбард. - Спб.: Питер Ком. - 2009. - 416 c

2. Антикризисный менеджмент/ М.Фрідмен, Р.Маржолен, Р.Прайк, - М.: Тандемэмос. $-2001 .-368$ с.

3. Дж.Гелбрейт. Основы приватизации и предпосылки. Пер. с англ./ Дж.Гелбрейт, Дж.Робінсон. - М.: «Дело». - 1992. - 702 с.
4. I. Бондар. Особенности нынешнего этапа реформирования/ I. Бондар, В. Беседин //Железнодорожный транспорт, 2002. - № 12. - С. 40-46.

5. Л. Верховодов. Проблемы и предпосылки эффективной реструктуризации предприятий/ Л. Верховодов, П. Кучерявенко// Экономика Украины. - 2000. - № 8. - С. 39-47.

6. Ю. Ехануров. Глобальні трансформації і стратегії розвитку різних форм власності. Монографія/ Ю. Ехануров, 3. Мочерний. - Одеса: НАН України. - 1998. - 416 с.

7. М. Чечетов. Основы приватизации и функционального управления убыточными предприятиями: Учеб.пособие/ М. Чечетов. - Спб.: Изд-во Михайлова В.А. - 1999. - 380 с.

8. Р. Євстигнєєв. Эффективное управление фирмой: современная теория и практика/ Р.Свстигнєєв, П.Буніч, В.Медведєв др. Спб.: Изд. дом «Бизнесс-пресса». - 1999. - 416 с.

УДК 656.224

\title{
ЛОГІСТИЧНИЙ ПІДХІД ДО ВЗАСМОДІЇ МАГІСТРАЛЬНОГО І ПРОМИСЛОВОГО ЗАЛІЗНИЧНОГО ТРАНСПОРТУ
}

\author{
Полякова О.М., к.е.н., доцент (УкрДУЗТ)
}

В статті розглянуто правові, технічні, технологічні та інформачійні аспекти взаємодіі магістрального $і$ промислового залізничного транспорту України,проаналізовано проблеми співпраці виробників $i$ перевізників у рамках транспортно-виробничих систем, доведено необхідність застосування логістичного підходу до розв'язання проблем взаємодії промислових комплексів із залізничним транспортом, визначено доцільність формування інформаційно-логістичного иентру 3 метою забезпечення координації та інтеграції взаємодії магістральних і промислових транспортних систем.

Ключові слова: промисловий залізничний транспорт, махістральний транспорт, логістичний підхід, інформаційно-логістичний центр.

\section{ЛОГИСТИЧЕСКИЙ ПОДХОД К ВЗАИМОДЕЙСТВИЮ МАГИСТРАЛЬНОГО И ПРОМЫШЛЕННОГО ЖЕЛЕЗНОДОРОЖНОГО ТРАНСПОРТА}

\section{Полякова Е.Н., к.э.н., доцент (УкрГУЖТТ)}

В статье рассмотрены правовые, технические, технологические и информационные аспекты взаимодействия магистрального и промышленного железнодорожного транспорта Украинь, проанализированы проблемы сотрудничества производителей и перевозчиков в рамках транспортнопроизводственных систем, доказана необходимость применения логистического подхода к решению проблем взаимодействия промышленных комплексов с железнодорожным транспортом, определена изелесообразность формирования информационно-логистического цеентра с целью обеспечения координации и интеграции взаимодействия магистральных и промышленных транспортных систем.

Ключевые слова: промышленный жселезнодорожсный транспорт, магистральный транспорт, логистический подход, информационно-логистический центр. 